\title{
The Design and Implementation for Undergraduate Teaching Work Management Systems of Universities in China
}

\author{
Shan-shan $\mathrm{YAN}^{1}$, Jing-xian $\mathrm{MA}^{2}$ and Ling-ling $\mathrm{WEI}^{3}$ \\ ${ }^{1}$ Office of Academic Affairs, Hebei University of Engineering, China \\ ${ }^{2}$ College of Arts, Hebei University of Engineering, China \\ ${ }^{3}$ Office of Academic Affairs, Hebei University of Engineering, China
}

\begin{abstract}
Keywords: University, Teaching management, Teaching work management, Undergraduate teaching work procedures.
\end{abstract}

\begin{abstract}
The undergraduate teaching work management system is the most important management system of universities. It can reflect scientific, standardized, systematic levels of universities management, as well as to establish the stable teaching order and provide guarantee to achieve the goal of the teaching work and personnel training. Based on the analysis of the current situation of universities teaching work management systems, this paper discuss the category and design principal of universities undergraduate teaching work management systems, as well as presents specific strategies to improve the design of the system and security measures to implement the system.
\end{abstract}

\section{Introduction}

Teaching management is an essential part of the school management. It means that the school administrators, through certain means, make the process of teaching activities achieve the personnel training objectives established by the schools. It aims to ensure the normal teaching order.

In China, on the basis of the respect for the law of education, teaching management regulation refers to the combination of the relevant rules and specifications that ensure the teaching activities be carried out smoothly. Teaching management regulation in higher education is the standardization of the teaching mode covering the philosophy of education and scientific study as well as the norms or guidelines which should be abode by teachers and students for handling teaching and learning affairs in the university.

According to the formation of teaching management regulation as well as its position and functions in higher education, it has the characteristics of rigidness and flexibility, broadness coupled with directivity, standardization together with induction and incitation with discipline. Teaching management regulation is manifested through text form. Only through concrete implementation can it embodies the design purpose and functional effect [1].

Undergraduate Teaching Management System is behavioral norm and procedure, which should be abode by administrators and teachers. In a sense, the system determines the teaching level of the university.

Undergraduate Teaching Management System is a necessary prerequisite to ensure the quality of teaching. It is a set of management principles and rules developed in the course of implementation and management as to achieve the desired effect of management. To make the daily teaching management work in normal operation, an orderly and stable management system is essential.

It will have important theoretical value and practical significance to explore the reform of the current undergraduate teaching management system with the guidance of 
new educational philosophy, as well as to establish a new system which is not only in line with teaching norms and standardization but encourages diversity and individuality.

\section{Unde rgraduate Teaching Manage ment System}

In China, undergraduate teaching management in universities is operated in the mode of two-level management by the university and colleges (sections), mainly managed by the latter. The president of the university has the overall charge of teaching work, while the vice-president is responsible for the daily teaching and evaluation by mobilizing the resources to serve the teaching activities and coordinating with relevant auxiliary sections so as to achieve the objectives of teaching management. Under the unified leadership of the Party Committee, the members of administrative meeting discuss and make decisions of the guiding ideologies, policies, plans and other major reform initiatives of teaching management.

Undergraduate Teaching Guidance Committee (hereinafter referred to as Teaching Guidance Committee) is a regularity body within the Academic Committee of the University. Under the leadership of the university president, the members of the committee are responsible for the study, consultation, guidance, evaluation and service of the teaching.

Undergraduate Teaching Supervision Group (hereinafter referred to as Teaching Supervision Group ) is set up to participate in teaching management, supervise teaching order and quality, provide guidance, teaching feedback and suggestions under the leadership of vice president in charge of teaching. There are relevant Teaching Supervision Groups in colleges (sections) responsible for the teaching work therein.

Academic Affairs Office is a functional department of undergraduate teaching management, under the leadership of the president, vice president in charge of teaching and teaching guidance committee, whose main responsibilities are as follows: implementing the teaching requirements of higher authorities, carrying out the decisions of the teaching work made by the university, organizing and managing teaching work, making rules and regulations of teaching management and coordinating services of relevant sections. Academic Affairs Office is responsible for the annual teaching evaluations of colleges (sections).

Colleges (sections) are responsible for the implementation, management and construction of the teaching of the unit. Deans (Directors) are the first responsible persons for teaching work. Vice deans (directors) in charge of teaching and Teaching Affairs Office are established, whose main responsibilities are as follows: implementing the guiding ideologies of the university, carrying out the unified arrangements of teaching, ensuring the stable teaching orders, doing research on the teaching laws of the unit, taking charge of the conventional teaching management and handling the daily administrative work of teaching. As basic teaching organizations, the institutional setting and directors (vice directors) are pointed by the departments (teaching and research offices, laboratories) independently. Directors of departments (teaching and research offices, laboratories) are in overall charge of teaching, carrying out various teaching tasks in accordance with the colleges (sections) regulations.

The settings and functions of teaching management in universities of America are quite different from that of China. In America, the dean of Academic Affairs Office is the head in charge of teaching and academic research. All matters related to teaching are operated by the coordination of Dean's Office, Student Affairs Office and the Departments. The Dean is responsible for the management of academic affairs, such as 
the setting of teaching programs and major plans, the management of teaching resources, the evaluation and recruitment of the teachers, the assessment of the teaching qualities; while student affair office takes charge in the enrollment of students, guidance of course selection, the management of student status, career guidance, student activities, etc. The implementation of teaching management in higher education gives priority to academic management, which coordinates with administrative management. The process of teaching management embodies the features of "management is service", "students- oriented" and "serving for the students' learning and development" [2].

American universities have full autonomy to decide major settings, which are not only diverse, but also cross penetrated of Science and Arts aiming to cultivate compound talents. The rich major settings provide a large space for students to achieve the goals of self-development. Students can take some minors according to their self-interests and career needs in addition to their majors. American higher education is mass education. There is only one big subject direction when students entering the university. The elective courses are all basic courses. In the third grade, students can select their majors according to their interests. The benefit of doing so is to let students understand the university as well as which majors they suit. However, students cannot selective whatever majors they want. Some popular majors have relatively high requirements. Students who meet the requirement can select the major they like.

The curriculum is broad and flexible, which emphasizes the breadth and depth of knowledge. U.S. colleges and universities aim to help students to gain useful knowledge as well as adapt to social development in the future. According to the feedback provided by students, Career Development Centers or Professional Associations, the members in Dean's Office will make some adjustments to the contradictions between students' abilities and social development in order to enhance students' occupational adaption.

Curriculum system includes four modules as follows: core courses of general education, professional compulsory courses, professional elective courses and elective courses. Each module has opened a number of courses for students to select. Students in the lower grades are required to take core courses of general education in order to lay the foundation for future professional learning. Based on the training objectives of each major, the university designs the major modules or the combination of courses for students. The curriculum setting of undergraduate education places much emphasis on the cultivation of students' practical skills and leadership abilities by providing various practice courses. In addition, rich and varied education programs are added to promote the comprehensive growth of the students. Such as Summer Reading Programs for freshmen aiming to cultivate students' reading interests, Honor Students Programs providing course guidance and centralized instruction for excellent students as well as other practice programs training students' capacities of research and innovation. The setting of these programs provides a broad platform for the development of students. In designing institution, sometimes the understanding of the whole meaning of the institution design is neglected; as a result, the institution design will deviate from the original route and lack internal logical relation. Particularly notable, there are no comprehensive and systematic statements on the covering contents and system structure in the management institution of work teaching in institution of higher learning

Throughout the management institution of teaching work in each institution of higher learning, institution system structures are different from each other. 
Based upon "undergraduate teaching work norms", the management system structure of undergraduate teaching is comprised of other regulations, rules, norms and methods.

"Henan University of Technology teaching work norms" includes teacher's moral cultivation, talent training, teacher qualification, teacher teaching responsibility, class teaching, practicing teaching, teaching management, and teaching awards and punishments.

Relevant regulations, rules, norms and methods are mainly included: teaching guiding committee regulation, teaching steering committee regulation, student information staff rules, teaching training management method, professional advice and management method, training plan management method, course construction management method, course teaching outline management method, experimental teaching regulations, practice management regulations, practice base construction and management work regulation, graduation project management method, examination management method, teaching material construction and management method, teaching quantity calculation method, class teaching quality evaluation method, teaching and research project management method, teaching results awarding method, outstanding teacher selection method and teaching accident defining method.

Based upon "teacher teaching work norms", the management system structure of undergraduate teaching is comprised of other regulations, rules, norms and methods.

\section{Management Institutional System Construction of Undergraduate Teaching Work}

In making "undergraduate teaching work norm", if the institution structure of " many principle articles, many implementation details" is adopted, then the merit is that sometimes the "undergraduate teaching work norm" does not need to be amended, supplementary or revised details are enough; but the shortcoming is that the management document lacks systematicness and logicality, making the user hard to grasp. If the system structure of " few principle articles, few implementation details" is adopted, then the merit is that it is easy for teaching management staff, teachers and students to get the hang of the policy; but the shortcoming is that it is no simple thing to amend.

This thesis suggests that the making of "undergraduate teaching work norm" shall be in contrast with "undergraduate teaching work review and evaluation plan" (2013), "undergraduate work level evaluation plan ( trial implementation)"2004, "the understanding of index connotation of undergraduate teaching work level evaluation plan" (evaluation office, 2009), undergraduate teaching quality assurance standard. Based upon the normalization and standardization of teaching work management, the principle of diversification, personalization and characteristic development, and the principle of avoiding to make sole norms, this thesis suggests to integrate original documents, supplement new rules, making the teaching management document more systematic, scientific, normative and flexible, pushing college's teaching work and making it easy for manage staff, teachers and students understand relevant policies.

This thesis suggests that the complicated or often-revised regulations, rules, norms, methods use principle articles in "undergraduate teaching work norms, and then solely make relevant regulations, rules, norms, methods. 


\section{Management Institutional Design Principle Of Undergraduate Teaching}

The way to solve existing issues in undergraduate teaching management institution is to comply with the benchmark of legitimacy, rationality, unitarity, systematicness and stability [3].

This thesis suggests the principles of management institution design of undergraduate teaching should be as follows:

Legitimacy Principle. The making of management institution of undergraduate teaching work shall comply with national laws and regulations, local regulations and national adminis trative department rules, combines with college's actual status to make targeted, pragmatic, operative management institution through legal procedures.

Scientific Normalization Principle. Scientificity requires the management institution of undergraduate teaching work to keep away from ambiguity and contradiction. Normalization requires teaching activities to accomplish under some certain norms.

Unitary Principle. The making of teaching management institution should be in accordance with college's entire operation institution, and also keeps in line with the whole teaching management institution.

People-Oriented and Flexible Principle. The ultimate goal of management institution of undergraduate teaching work is to trigger people's initiative and creativity, thus improving teaching quality. The system construction should be people-oriented, which means its start point should be people, all the institutional arrangements and policy measures shall embody humanity, respect human rights, and also they cannot surpass human's developmental stage and neglect human's needs. The specialty of teachers work and features of student's development should be sufficiently considered, the flexibility of teaching management shall be reinforced, teacher and student's personalities and creativity shall be respected and protected, teacher's teaching autonomy and student's learning freedom shall be protected.

Ope rability principle. The making of management institution of teaching work shall be based upon the completion of teaching's basic demands, and ensure clear thoughts, definite objective and precise norm, trying to make it easy for implementation with strong operability.

\section{Design Strategies of Undergraduate Teaching Manage ment System}

The main focus of this paper is Undergraduate Teaching Regulation and its implementation details. The core contents of Undergraduate Teaching Regulation are construction of teaching staff, professional talent training scheme, curriculum construction, curriculum assessment methods, calculation method of teaching workload and monitoring system of teaching quality.

\section{Construction of Teaching Staff}

Teachers are the most important teaching resources. Teachers of high qualities are the basic guarantees of teaching levels. It is vital to construct teaching teams which are reasonable in ages, educational backgrounds, professional ranks and titles and academic structures to meet the need of talents training.

In accordance with the requirements of Long-term Education Reform and Development Plan (2010-2020) and Long-term Talent Development Plan (2010-2020), Ministry of Education has set up Cultivating Initiative of Excellent Engineers (referred to as "Excellent Initiative"). 
According to the characteristics of "Excellent Initiative", universities should put forward higher requirements on teachers, especially young teachers. In the formulation of Undergraduate Teaching Regulations, some entrenched clauses have being added, for instance, "on the basis of their own majors, young teachers should participate in full-time practice training in enterprises, research institutes or other relevant units organized by the Colleges (Sections) at least once for a period of 3 months to 1 year". As a result, young teachers can improve their practice abilities and experience, so as to better implement "Excellent Initiative".

\section{Professional Talent Training Sche me}

The basic task of universities is to cultivate talents. The set up of Talent Training Scheme is the first and foremost step to carry out this task. The objectives and specifications of talent training determine what kinds of talents universities cultivate. The set up of teaching scheme reflects how universities train their students. Talent Training Scheme is the guideline in the process of teaching, which embodies the school-running orientation, teaching level and characteristics of the university.

Three problems should be paid attention to in the management of Talent Training Scheme.

\section{The Problem of Normalization}

Talent Training Scheme should include training objectives, major standards, specifications, knowledge structures, curriculum system, main courses, credits, graduation qualifications, and degrees and so on. Talent Training scheme should be consistent with the training objectives. The establishment of the scheme should be able to properly reflect the coordinated development of knowledge, ability and quality. Examination and approval procedures should be set up, as well as the monitoring and evaluation system in order to ensure the effective implementation of the scheme.

\section{The Problem of Standardization}

Training standards are the basic requirements of all the aspects set by the university for talent training. Such as the moral standard or learning ability students should reach. Different types of universities have different training objectives, so do the training standards. Universities should determine the standards of all aspects scientifically and reasonably so as to guide teaching and ensure to achieve the objectives of talent training.

Different types of school due to different training objectives, training is not the same standard. Basic requirements, the school should be scientifically and reasonably determine all aspects of quality standards in all aspects of quality standards should be able to guide the work of the teaching process, ensure personnel training objectives.

\section{The Problem of Characteristics}

It is very important to set up a talent training framework which is multi- channel, multi-standard as well as has various modules so as to focus on practical teaching and cultivate students' innovation abilities. In Undergraduate Teaching Regulations, more free space should be given to the teachers. For example, according the real situations, teachers can change or adjust the content of the courses, innovate the teaching methods or make evaluation methods independently. 


\section{Curriculum Construction}

Curriculum is the fundamental basis for teaching, as well as the basic guarantee to achieve the goals of education, which plays a decisive role in the comprehensive development of students [4].

Curriculum is the combination of the university and students. The former provides curriculum, while the latter learn. Curriculum is also the combination of the university and society. The different requirements for the talents (students) by society should be achieved by the changes of curriculum content and structures. Curriculum is the combination of teaching and scientific research. Scientific research can promote teaching because the curriculum is the carrier. To strengthen the curriculum construction, administrators should place much emphasis on the course construction, change teaching concepts, explore teaching methods and reform evaluation system [5].

With regard to curriculum construction, the focus should lay on the build of curriculum standards (for students) and teaching syllabus (for teachers). The administrators should rely on the departments or teachers when formulating curriculum standards sand teaching syllabus; meanwhile they should also follow the advice of staff from outside enterprises and alumni.

MOOCs is an effective means of talents training through which can achieve school-enterprise cooperation. The problem of hiring enterprises personnel to give lectures in universities is that they do not have enough time. Therefore, the courses taught by enterprises personnel can be made in the form of MOOCs and they can offer tutoring to students irregularly, through which will save a lot of time and make it operable for universities to open undergraduate courses by enterprise personnel.

\section{Safeguard Measures of Implementing Management System of Undergraduate Teaching Work}

It doesn't mean that the teaching management regulations automatically take effect immed iately after they are established. However, during the process practicing teaching management regulations, some problems often appear due to kinds of reasons. Individuals don't necessarily carry out relevant teaching management rules and regulations from school positively. Therefore, whether the teaching management regulations can be implemented smoothly and the implementation results depend on whether the participants are inspired and whether enough and necessary resources are acquired to implement the teaching management policy [1].

Establish the improved faculty assessment system reflecting scientific outlook on development and correct requirements of review on achievements and playing the inspiring and guiding role of assessment fully have the important realistic significance in motivating the working enthusiasm of school faculty and cadres and promoting the scientific development of school career[6].

\section{References}

[1] J. Sci. Commun. 163 (2000) 51-59. Liu, L. Q, Analysis on implemental effect of teaching rulesand regulations in college and university. Master Dissertation, 2006.

[2] W. Zhao, The Characteristics and enlightenment of American university education teaching management -A case study of Florida international university. Guangdong Chemical Jpurnal. 40(2013)184, 191. 
[3] B. Zhang, The retrospect of ten-year research on teaching management system of undergraduate universities. Research on Higher Engineering Education. 3(2009)127131.

[4] X.J. Liu, The development tendency of college curricula construction. Journal of Higher Education. 35 (2014)62-69.

[5] X.J. Liu, Grasp four key problems to strengthen the construction of university undergraduate course. China Higher Education. 17(2013)40-43.

[6] W.D. Luo, Construction and exploration of faculty evaluation system in Colleges and Universities. China Higher Education. 18(2011)22-24. 